\title{
TINGKAT KEPUASAN PASIEN PADA PELAYANAN BALAI PENGOBATAN GIGI DI PUSKESMAS PETANAHAN KEBUMEN
}

\author{
Wiworo Haryani*, Aulia Nur Atikah, Aryani Widayati \\ Jurusan Keperawatan Gigi Poltekkes Kemenkes Yogyakarta \\ Jl. Kyai Mojo No 56, Pingit, Yogyakarta 55243, 0823-2798-8251 \\ E-mail* : haryaniwiworo@gmail.com
}

\begin{abstract}
Satisfaction is a feeling or perception of patients arising from the health performance that occurs after the patient compared to what to expect. The number of patients visited Dental Service Center at Petanahan Community Health Center Kebumen in October-November 2016 went up and down. This reaserch is aimed to know patients' satisfaction level at the Dental Service Center at Petanahan Community Health Center, Kebumen. The type of research was descriptive research. The research was conducted at Petanahan Community Health Center, Kebumen. The number of samples was 40 respondents with determination of the sample by purposive sampling. Criteria of respondent were 20-45 years old, graduated from junior high school (minimum), and willing to be the research respondent. The patients' satisfaction level research was conducted after the patient received dental and oral health care and completed a questionnaire containing 20 statements. The results showed the satisfaction level of patients in the category of very satisfied as much as 26 respondents (65\%). Patient satisfaction level seen from the comfort dimension showed $60 \%$ of respondents are very satisfied, seen from the dimensions of reliability and professionalism officials $70 \%$ of respondents feel very satisfied and seen from the dimensions of responsiveness and empathy $67.5 \%$ of respondents feel very satisfied. It can be concluded that the level of patient satisfaction on Dental Service Center Puskesmas Petanahan Kebumen entered in the category very satisfied as much as 26 respondents (65\%).
\end{abstract}

Keywords : Level of Satisfaction, Patient, Dental Service Center

\section{ABSTRAK}

Kepuasan adalah suatu tingkat perasaan atau persepsi pasien yang timbul sebagai akibat dari kinerja pelayanan kesehatan yang diperoleh setelah pasien membandingkan dengan apa yang diharapkan. Jumlah kunjungan pasien bulan OktoberNovember 2016 pada pelayanan Balai Pengobatan Gigi di Puskesmas Petanahan Kebumen mengalami fluktuasi. Tujuan penelitian ini untuk mengetahui tingkat kepuasan pasien pada pelayanan Balai Pengobatan Gigi di Puskesmas Petanahan Kebumen. Jenis penelitian yang digunakan adalah penelitian deskriptif. Lokasi penelitian ini di Puskesmas Petanahan Kebumen. Penelitian dilaksanakan pada bulan Maret-April 2017. Jumlah sampel adalah 40 responden dengan penentuan sampel secara purposive sampling. Kriteria responden berumur 20-45 tahun, pendidikan terakhir minimal SMP dan bersedia menjadi responden. Penilaian tingkat kepuasan pasien dilakukan setelah pasien mendapatkan pelayanan kesehatan gigi dan mulut dan telah mengisi kuesioner yang berisi 20 pernyataan. Hasil penelitian menunjukkan tingkat kepuasan pasien dinyatakan dalam kategori sangat puas sebanyak 26 responden (65\%). Tingkat kepuasan pasien dilihat dari dimensi kenyamanan menunjukkan $60 \%$ responden menyatakan sangat puas, dilihat dari dimensi kehandalan dan profesionalisme petugas $70 \%$ responden merasa sangat puas dan dilihat dari dimensi daya tanggap dan empati $67,5 \%$ responden merasa sangat puas. Kesimpulan dari hasil penelitian yaitu tingkat kepuasan pasien pada Pelayanan Balai Pengobatan Gigi Puskesmas Petanahan Kebumen masuk dalam kategori sangat puas dengan jumlah 26 responden (65\%).

Kata Kunci : Tingkat Kepuasan, Pasien, Pelayanan Balai Pengobatan Gigi

\section{PENDAHULUAN}

Tujuan pembangunan kesehatan adalah tercapainya kemampuan untuk hidup sehat bagi setiap penduduk agar dapat mewujudkan derajat kesehatan yang optimal, sebagai salah satu unsur kesejahteraan umum dari tujuan nasional. Dalam Sistem Kesehatan Nasional (SKN) dikemukakan pentingnya sumber daya yang mendukung upaya tersebut yaitu : upaya kesehatan, pembiayaan kesehatan, sumber daya manusia kesehatan, sediaan farmasi, alat kesehatan, manejemen dan informasi kesehatan, IImu Pengetahuan dan Teknologi (IPTEK). ${ }^{1}$ Salah satu dari sasaran pembangunan kesehatan dalam rangka mewujudkan
Indonesia Sehat 2025 dalam bidang upaya kesehatan adalah diselenggarakannya pembangunan kesehatan guna menjamin tersedianya upaya kesehatan, baik upaya kesehatan masyarakat maupun upaya kesehatan perorangan yang bermutu, merata, dan terjangkau oleh masyarakat. Upaya kesehatan diselenggarakan dengan pengutamaan pada upaya pencegahan (preventif), dan peningkatan kesehatan (promotif) bagi segenap warga negara Indonesia, tanpa mengabaikan upaya penyembuhan penyakit (kuratif), dan pemulihan kesehatan (rehabilitatif) ${ }^{2}$.

Pelayanan kesehatan merupakan upaya yang diselenggarakan sendiri atau secara bersama-sama 
dalam suatu organisasi untuk memelihara dan meningkatkan kesehatan, mencegah dan menyembuhkan penyakit serta memulihkan kesehatan perorangan, keluarga, kelompok dan atupun masyarakat ${ }^{3}$.

Pelayanan kesehatan gigi dan mulut adalah pelayanan kesehatan profesional yang ditujukan kepada masyarakat, keluarga maupun peroranganbaik yang sakit maupun yang sehat. Pelayanan kesehatan gigi dilakukan untuk memelihara dan meningkatkan derajat kesehatan masyarakat dalam bentuk peningkatan kesehatan gigi, pencegahan penyakit gigi, pengobatan penyakit gigi dan pemulihan kesehatan gigi oleh pemerintah yang dilakukan secara terpadu, terintegrasi dan berkesinambungan ${ }^{4}$.

Keberhasialan yang diperoleh suatu pelayanan kesehatan dalam meningkatkan mutu pelayanan berhubungan erat dengan kepuasan pasien5. Kepuasan pasien adalah suatu tingkat perasaan atau persepsi pasien yang timbul sebagai akibat dari kinerja layanan kesehatan yang diperoleh setelah pasien membandingkan dengan apa yang diharapkan ${ }^{6}$. Kepuasan pasien berhubungan erat dengan berbagai kondisi sehat dan perilaku sakit. Pasien yang puas akan patuh pada instruksi dan meneruskan perawatan selanjutnya. Setiap pasien yang mengunjungi suatu unit pelayanan kesehatan mempunyai keinginan atau harapan kepuasan dalam perawatan. Kebutuhan dan harapan terhadap pelayanan yang cepat dan tepat, biaya pengobatan yang murah, tenaga medis yang terampil serta sikap yang ramah dan komunikatif adalah sebagian dari tuntutan pasien, tetapi hanya sebagian pelayanan kesehatan yang mampu memenuhi tuntutan tersebut ${ }^{7}$.

Data yang penulis dapatkan dari buku register Balai Pengobatan Gigi Puskesmas Petanahan Kebumen menunjukkan jumlah kunjungan pasien dari bulan Oktober-Desember 2016 mengalami fluktuasi, dengan rincian bulan Oktober jumlah kunjungan 240 pasien, bulan November 227 pasien dan bulan Desember 245 pasien. Fluktuasi juga terjadi pada jumlah tindakan perawatan scaling. Rata-rata $25 \%$ pasien yang datang ke Balai Pengobatan Gigi Puskesmas Petanahan Kebumen mendapatkan tindakan perawatan jaringan pulpa gigi, dengan rincian pada bulan Oktober jumlah perawatan jaringan pulpa yaitu 60 tindakan, bulan November 68 tindakan dan bulan Desember 2016 yaitu 80 tindakan ${ }^{8}$.

Tujuan dari penelitian yang akan dilaksanakan adalah untuk mengetahui tingkat kepuasaan pasien pada pelayanan Balai Pengobatan Gigi di Puskesmas
Petanahan Kebumen dilihat dari dimensi sarana prasarana dan kenyamanan, kehandalan dan profesionalisme, serta daya tanggap dan empati tenaga kesehatan Balai Pengobatan Gigi. Manfaat dari penelitian yang akan dilaksanakan diharapkan hasil penelitian memberikan data atau informasi yang dapat digunakan sebagai bahan pustaka untuk meningkatkan kualitas pelayanan kesehatan khususnya Balai Pengobatan Gigi di Puskesmas Petanahan Kebumen. Penelitian ini diajukan kaji etik ke Komisi Etik Penelitian Kesehatan Poltekkes Kemenkes Yogyakarta dengan nomor LB.01.01/KE01/XXIV/587/2017.

\section{METODE}

Jenis penelitian yang digunakan adalah penelitian deskriptif. Populasi pada penelitian ini adalah seluruh pasien yang datang ke Balai Pengobatan Gigi Puskesmas Petanahan Kebumen selama masa penelitian yakni pada bulan Maret-April 2017 dengan kriteria inklusi: bersedia menjadi responden, umur 20 45 tahun, pendidikan terakhir minimal SMP. Besar sampel dalam penelitian ini adalah $15 \%$ dari jumlah populasi yaitu 40 orang responden yang datang ke Balai Pengobatan Gigi Puskesmas Petanahan Kebumen yang diambil dengan teknik purposive sampling. Responden akan diberikan kuesioner setelah mendapatkan pelayanan di Balai Pengobatan Gigi Puskesmas Petanahan Kebumen.

Instrumen dalam penelitian ini adalah kuesioner tentang tingkat kepuasan pasien. Penilain tingkat kepuasan pasien dilihat dari pilihan jawaban dengan urutan perasaan dari terendah ke tinggi melalui ketentuan kode 1 s.d. 5 yaitu, tidak puas, kurang puas, cukup puas, puas, dan sangat puas. Data yang diperoleh akan diolah menggunakan program komputer.

\section{HASIL PENELITIAN}

Tabel 1. Distribusi Tingkat Kepuasan Responden Berdasarkan Pelayanan yang Diberikan

\begin{tabular}{lcc}
\hline \multirow{2}{*}{ Kategori } & Jumlah & Persentase \\
\cline { 2 - 3 } & $\mathbf{n}$ & $\%$ \\
\hline Kurang Puas & 1 & 2,5 \\
Puas & 13 & 32,5 \\
Sangat Puas & 26 & 65 \\
\hline Jumlah & 40 & 100 \\
\hline
\end{tabular}

Berdasarkan tabel 1 menunjukkan bahwa sebanyak 26 responden (65\%) merasa sangat puas terhadap pelayanan yang diberikan. 
Tabel 2. Distribusi Tingkat Kepuasan Dilihat dari Dimensi Kenyamanan

\begin{tabular}{lcccccccc}
\hline \multirow{1}{*}{ Kategori } & \multicolumn{2}{c}{$\begin{array}{c}\text { Kurang } \\
\text { Puas }\end{array}$} & \multicolumn{2}{c}{ Puas } & \multicolumn{2}{c}{$\begin{array}{c}\text { Sangat } \\
\text { Puas }\end{array}$} & \multicolumn{2}{c}{ Jumlah } \\
\cline { 2 - 9 } & $\mathbf{n}$ & $\%$ & $\mathbf{n}$ & $\%$ & $\mathbf{n}$ & $\%$ & $\mathbf{n}$ & $\%$ \\
\hline $\begin{array}{l}\text { Kenyamanan ruang } \\
\text { periksa }\end{array}$ & 2 & 5 & 10 & 25 & 28 & 70 & 40 & 100 \\
\hline $\begin{array}{l}\text { Kenyamanan ruang } \\
\text { tunggu }\end{array}$ & 1 & 2,5 & 10 & 25 & 29 & 72,5 & 40 & 100 \\
\hline $\begin{array}{l}\text { Kelengkapan alat dan } \\
\text { bahan }\end{array}$ & 0 & 0 & 8 & 20 & 32 & 80 & 40 & 100 \\
\hline $\begin{array}{l}\text { Kebersihan dan } \\
\text { kerapihan petugas }\end{array}$ & 0 & 0 & 8 & 20 & 32 & 80 & 40 & 100 \\
\hline $\begin{array}{l}\text { Kondisi peralatan yang } \\
\text { digunakan }\end{array}$ & 0 & 0 & 11 & 27,5 & 29 & 72,5 & 40 & 100 \\
\hline $\begin{array}{l}\text { Jenis perawatan yang } \\
\text { tersedia }\end{array}$ & 1 & 2,5 & 9 & 22,5 & 30 & 75 & 40 & 100 \\
\hline
\end{tabular}

Tabel 2 menunjukkan kepuasan ditinjau dari dimensi kenyamanan, dimana pasien merasa sangat puas dengan kelengkapan alat bahan yaitu sebesar $80 \%$ serta kebersihan dan kerapihan petugas yaitu sebesar $80 \%$. Pasien merasa kurang puas dengan kenyamanan ruang periksa dengan jumlah pasien yang memilih kategori kurang puas sebanyak 2 pasien $(5 \%)$.

Tabel 3 menunjukkan kepuasan pasien ditinjau dari dimensi kehandalan dan profesionalisme dimana pasien mersa sangat puas terhadap ketelitian petugas dengan jumlah pasien yang memilih kategori sangat puas sebanyak 35 pasien $(87,5 \%)$, namun ada 1 pasien $(2,5 \%)$ yang memberikan penilaian kurang puas terhadap keterampilan petugas, keahlian petugas, ketelitian, kejelasan memberikan instruksi, kedisiplinan petugas.

Tabel 3.Distribusi Tingkat Kepuasan Dilihat Dari Dimensi Kehandalan Dan Profesionalisme

\begin{tabular}{lcccccccc}
\hline \multirow{2}{*}{ Kategori } & \multicolumn{1}{c}{ Kurang Puas } & \multicolumn{2}{c}{ Puas } & \multicolumn{3}{c}{ Sangat Puas } & \multicolumn{2}{c}{ Jumlah } \\
\cline { 2 - 10 } & $\mathbf{n}$ & $\%$ & $\mathbf{n}$ & $\%$ & $\mathbf{n}$ & $\%$ & $\mathbf{n}$ & $\%$ \\
\hline $\begin{array}{l}\text { Keterampilan } \\
\text { petugas }\end{array}$ & 1 & 2,5 & 6 & 15 & 33 & 82,5 & 40 & 100 \\
\hline $\begin{array}{l}\text { Keahlian petugas } \\
\text { Kecepatan tindakan }\end{array}$ & 1 & 2,5 & 7 & 17,5 & 32 & 80 & 40 & 100 \\
$\begin{array}{l}\text { perawatan } \\
\text { Ketelitian petugas }\end{array}$ & 1 & 2,5 & 6 & 15 & 33 & 82,5 & 40 & 100 \\
\hline $\begin{array}{l}\text { Kejelasan } \\
\text { memberikan } \\
\text { instruksi }\end{array}$ & 1 & 5 & 5 & 15 & 34 & 85 & 40 & 100 \\
\hline $\begin{array}{l}\text { Kemudahan } \\
\text { administrasi }\end{array}$ & 0 & 0 & 10 & 25 & 30 & 75 & 40 & 100 \\
\hline $\begin{array}{l}\text { Kedisiplinan } \\
\text { petugas }\end{array}$ & 1 & 2,5 & 9 & 22,5 & 30 & 75 & 40 & 100 \\
\hline
\end{tabular}

Tabel 4. Distribusi Kepuasan Responden Dilihat Dari Dimensi Empati

\begin{tabular}{lcccccccc}
\hline \multicolumn{1}{c}{ Kategori } & \multicolumn{1}{c}{ Kurang Puas } & \multicolumn{2}{c}{ Puas } & \multicolumn{3}{c}{ Sangat Puas } & \multicolumn{2}{c}{ Jumlah } \\
\cline { 2 - 9 } & $\mathbf{n}$ & $\%$ & $\mathbf{n}$ & $\%$ & $\mathbf{n}$ & $\%$ & $\mathbf{n}$ & $\%$ \\
\hline Keramahan petugas & 1 & 2,5 & 7 & 17,5 & 32 & 80 & 40 & 100 \\
\hline $\begin{array}{l}\text { Kesungguhan petugas } \\
\text { menangani keluhan }\end{array}$ & 1 & 2,5 & 7 & 17,5 & 32 & 80 & 40 & 100 \\
\hline $\begin{array}{l}\text { Perhatian petugas } \\
\text { dalam memberi } \\
\text { pelayanan }\end{array}$ & 1 & 2,5 & 7 & 17,5 & 32 & 80 & 40 & 100 \\
\hline $\begin{array}{l}\text { Pelayanan tanpa } \\
\text { memandang status }\end{array}$ & 1 & 2,5 & 7 & 17,5 & 32 & 80 & 40 & 100 \\
\hline $\begin{array}{l}\text { Sosial } \\
\text { Kesopanan petugas } \\
\text { Dorongan menangani }\end{array}$ & 1 & 2,5 & 7 & 17,5 & 32 & 80 & 40 & 100 \\
kecemasan & 1 & 2,5 & 9 & 22,5 & 30 & 75 & 40 & 100 \\
\hline Kesempatan bertanya & 1 & 2,5 & 9 & 22,5 & 30 & 75 & 40 & 100 \\
\hline
\end{tabular}

Tabel 4 menunjukkan bahwa tingkat kepuasan dilihat dari dimensi empati yang meliputi keramahan petugas, kesungguhan petugas menangani keluhan, perhatian petugas dalam memberikan pelayanan, pelayanan tanpa memandang status sosial, dan kesopanan petugas pasien memberikan penilaian dengan kategori sangat puas sebanyak 32 pasien
(80\%), puas 7 pasien $(17,5 \%)$ dan 1 pasien $(2,5 \%)$ memberikan penilaian kurang puas.

Hasil penelitian mengenai tingkat kepuasan dilihat dari dimensi kenyamanan, kehandalan dan profesionalisme, serta daya tanggap dan empati adalah sebagai berikut: 
Tabel 5. Distribusi Tingkat Kepuasan Responden Dengan Dimensi Kenyamanan, Kehandalan Dan Profesionalisme, Serta Daya Tanggap Dan Empati

\begin{tabular}{lcccccc}
\hline $\begin{array}{c}\text { Tingkat } \\
\text { Kepuasan }\end{array}$ & \multicolumn{2}{c}{ Kenyamanan } & \multicolumn{2}{c}{$\begin{array}{c}\text { Kehandalan dan } \\
\text { profesionalisme }\end{array}$} & $\begin{array}{c}\text { Daya tanggap dan } \\
\text { empati }\end{array}$ \\
\cline { 2 - 7 } & $\begin{array}{c}\text { Jumlah } \\
(\mathbf{n})\end{array}$ & $\begin{array}{c}\text { Persentase } \\
(\mathbf{\%})\end{array}$ & $\begin{array}{c}\text { Jumlah } \\
(\mathbf{n})\end{array}$ & $\begin{array}{c}\text { Persentase } \\
(\%)\end{array}$ & $\begin{array}{c}\text { Jumlah } \\
(\mathbf{n})\end{array}$ & $\begin{array}{c}\text { Persentase } \\
(\%)\end{array}$ \\
\hline Kurang Puas & 0 & 0 & 0 & 0 & 1 & 2,5 \\
Puas & 16 & 40 & 12 & 30 & 12 & 30 \\
Sangat Puas & 24 & 60 & 28 & 70 & 27 & 67,5 \\
\hline Total & 40 & 100 & 40 & 100 & 40 & 100 \\
\hline
\end{tabular}

Kepuasan di tinjau dari dimensi kenyamanan (Tabel 5) menunjukkan bahwa 16 responden (40\%) merasa puas dan 24 responden (60\%) merasa sangat puas. kepuasan responden terhadap pelayanan Balai Pengobatan Gigi Puskesmas Petanahan Kebumen di tinjau dari dimensi kehandalan dan profesionalisme menunjukkan bahwa 12 responden $(30 \%)$ merasa puas dan 28 responden $(70 \%)$ merasa sangat puas sedangkan di tinjau dari dimensi daya tanggap dan empati 1 responden (2,5\%) merasa kurang puas, 12 responden $(30 \%)$ merasa puas dan 27 responden $(67,5 \%)$ merasa sangat puas .

\section{PEMBAHASAN}

Hasil penelitian menunjukkan bahwa pasien merasa sangat puas dengan pelayanan yang telah diberikan. Dilihat dari dimensi sarana prasarana dan kenyamanan mayoritas pasien merasa sangat puas. Fasilitas seperti kerapihan, kanyamanan, kebersihan dari ruang perawatan atau klinik sangat mempengaruhi kepuasan pasien. Penelitian berdasarkan dimensi kenyamanan menunjukkan bahwa $40 \%$ merasa puas dan $60 \%$ pasien merasa sangat puas, penampilan pelayanan tidak hanya sebatas pada tampilan fisik bangunan tetapi juga penampilan petugas dan ketersediaan saranan prasarana penunjang ${ }^{9}$.

Tingkat kepuasan pasien pada penelitian ini dilihat dari dimensi kehandalan dan profesionalisme termasuk dalam kategori sangat puas. Petugas kesehatan gigi dan mulut dalam melakukan suatu tindakan harus melakukan dengan kinerja yang sesuai dengan harapan pasien yang berarti ketepatan waktu, pelayanan yang sama untuk semua pasien, sifat yang simpatik dan akurasi yang tinggi. Hasil penelitian kepuasan pasien berdasarkan dimensi pelayanan kehandalan diperoleh $70 \%$ pasien merasa sangat puas dan $30 \%$ pasien merasa puas. $84,5 \%$ pasien merasa sangat puas dengan kinerja dokter gigi karena kedisiplinan dokter gigi ${ }^{10}$.

Hasil penelitian kepuasan pasien berdasarkan dimensi pelayanan empati diperoleh hasil sebesar $67,5 \%$ dengan kategori sangat puas, pasien merasa sangat puas dengan keramahan dan kesopanan petugas dalam memberikan pelayanan serta petugas yang tidak membedakan status sosial pasien yang menjadikan pasien merasa nyaman dan berkeinginan untuk datang kembali dikemudian hari. Perilaku petugas yang menenangkan pasien, petugas yang mendengarkan keluhan pasien, pelayanan yang tidak membedakan status sosial pasien menyebabkan pasien memberikan penilaian yang baik11. Kepuasan pasien terhadap dimensi empati yang disebabkan karena petugas kesehatan gigi dan mulut telah memberikan perhatian dan sikap peduli yang tulus terhadap keluhan yang disampaikan pasien sehinngga menimbulkan kepuasan pasien pada pelayanan tersebut ${ }^{12}$.

\section{KESIMPULAN}

Kesimpulan dalam penelitian ini adalah tingkat kepuasan pasien Balai Pengobatan Gigi Puskesmas Petanahan Kebumen berdasarkan pelayanan yang diberikan, kenyamanan, kehandalan dan profesionalisme, daya tanggap dan empati dinyatakan dalam kategori sangat puas yang berarti pelayanan Balai Pengobatan Gigi Puskesmas Petanahan Kebumen sudah sesuai dengan harapan pasien.

\section{SARAN}

Berdasarkan hasil yang diperoleh dari penelitian ini, maka diajukan saran-saran sebagai pelengkap kualitas pelayanan yang akan diberikan untuk mempertahankan dan meningkatkan kepuasan pasien yang berkunjung ke Balai Pengobatan Gigi Puskesmas Petanahan Kebumen, yaitu puskesmas perlu melakukan pembenahan pelayanan dan pengembangan jenis pelayanan di balai pengobatan gigi sesuai permintaan dan kebutuhan penyakit gigi yang ada di masyarakat. Kepada peneliti-peneliti yang tertarik untuk meneliti tentang tingkat kepuasan untuk melakukan penelitian yang lebih lanjut dan lebih spesifik dengan metode, desain dan dimensi kepuasan yang berbeda.

\section{DAFTAR PUSTAKA}

1. Departemen Kesehatan RI. 2009. Sistem Kesehatan Nasional, Bentuk dan Cara Penyelenggaraan Pembangunan Kesehatan. Jakarta: Departemen Kesehatan . h. 4-11.

2. 2010. Profil

Kesehatan Indonesia. Jakarta: Departemen 
Kesehatan. h. 61-96.

3. Dewan Perwakilan Rakyat Republik Indonesia. 2009. Undang-undang Nomor 36 Tahun 2009 tentang Kesehatan. Jakarta.

4. Muninjaya, A.A.G. 2011. Manajemen Mutu Pelayanan Kesehatan. Jakarta: EGC. h. 12-16.

5. Sudian,T. Hubungan Kepuasan Pasien terhadap Mutu Pelayanan Kesehatan di Rumah Sakit Cut Mutia Kabupaten Aceh Utara. Jurnal. STIKES U'Budiyah. 2011. h. 1.

6. Nur, S. 2011. Pengaruh Komunikasi Terapeutik Perawat Terhadap Kepuasan Pasien di Rumah Sakit Haji. Tesis. Sumatera Utara: Universitas Sumatera Utara. h. 27.

7. Simbolon, R. 2011. Tingkat Kepuasan Pasien Terhadap Pelayanan Kesehatan Gigi dan Mulut di RSUD Dr. Djaramen Seragih Pemtangsiantar. Tesis. Universitas Sumatera Utara: Sumatera Utara. h. 1-19.

8. Puskesmas Petanahan. 2016. Buku Registrasi Balai Pengobatan Gigi. Kebumen: Puskesmas
Petanahan.

9. Nanza, M. R. 2015. Gambaran Tingkat Kepuasan Pasien pada Pelayanan Poliklinik Gigi dan Mulut di Puskesmas Kota Banda Aceh. Skripsi. Banda Aceh: Universitas Syah Kuala Darussalam Banda Aceh. h. 34-41.

10.Rizal, Achmad., Yeni, Riza. Hubungan Kualitas Pelayanan Kesehatan dengan Tingkat Kepuasan Pasien di BP. Gigi Puskesmas Kelayan Dalam Kota Banjarmasin. Jurnal. Fakultas Kesehatan Masyarakat UNISKA. 2014; 1(1); h.26-31.

11.Mumu, Like.J., Grace D. Kondou., Diana, V. Doda. Faktor-faktor yang Berhubungan dengan Kepuasan Pasien di Poliklinik Penyakit Dalam RSUP.Prof. Dr. R.D. Kondou Manado. Jurnal Universitas Sam Ratulangi Manado. 2015. h. 5.

12.Sembel, M., Henry, O.,Bernart, S, P, H. Gambaran Tingkat Kepuasan Pasien Terhadap Perawatan Gigi dan Mulut di Puskesmas Bahu. Jurnal e-Gigi. 2014; 2(2); h. 57-66. 